Western North American Naturalist 67(3), ㄷ 2007, pp. 409-428

\title{
WATERFOWL DISTRIBUTION AND ABUNDANCE DURING SPRING MIGRATION IN SOUTHERN OREGON AND NORTHEASTERN CALIFORNIA
}

\author{
Joseph P. Fleskes ${ }^{1}$ and Julie L. Yee ${ }^{2}$
}

\begin{abstract}
We used aerial surveys to study abundance and distribution of waterfowl (ducks, geese, swans, and coots) during spring in southern Oregon and northeastern California (SONEC). Total waterfowl-use days in SONEC during the 119-day, 5 January-3 May, spring period was similar during $2002(127,977,700)$ and $2003(128,076,200)$ and averaged 1,075,900 birds per day (bpd); these estimates should be adjusted upward 4\%-10\% to account for areas not surveyed. Waterfowl abundance peaked in mid-March in both years: 2,095,700 in 2002 and 1,681,700 in 2003. Northern Pintail (Anas acuta) was the most abundant species in both years, accounting for $25.6 \%$ of the 2002 and $24.5 \%$ of the 2003 waterfowl-use days. Pintail abundance peaked during the 13 March survey at 689,300 in 2002 and 532,100 in 2003. All other dabbling ducks accounted for $27.6 \%$ and $28.6 \%$, diving ducks for $13.5 \%$ and $9.2 \%$, geese for $24.6 \%$ and $29.3 \%$, swans for $2.8 \%$ and $1.9 \%$, and coots for $5.8 \%$ and $6.4 \%$ of the spring waterfowl-use days in SONEC during 2002 and 2003, respectively. Although use days changed little for total waterfowl $(+0.08 \%)$ and dabbling ducks $(-0.1 \%)$, diving duck use was lower $(-32 \%)$, and goose use days were greater $(+19 \%)$ in 2003 than in 2002 . Distribution was similar in both years, with the most waterfowl use in the Lower (66\%) and Upper (14\%) Klamath subregions; $2 \%-6 \%$ occurred in each of the other subregions. Although the Lower Klamath subregion received the greatest overall waterfowl use, distribution among subregions varied among species and surveys, and all subregions were important during some part of the spring for 1 or more species. Peak spring abundance in SONEC during 2002 and 2003 averaged $50.3 \%$ of the midwinter abundance in California (all survey regions) and southern Oregon (69-3 survey region) for all waterfowl, 46.1\% for dabbling ducks, $62.4 \%$ for diving ducks, $68.8 \%$ for geese, $109.4 \%$ for swans, and $43.8 \%$ for coots. Each spring, $75 \%$ of all waterfowl use in SONEC occurred on federal, state, or Nature Conservancy lands (i.e., protected areas). On protected areas there was a higher percentage of dabbling ducks (80.5\%), geese (70.5\%), and coots (81.5\%) than diving ducks $(60.4 \%)$ and swans (49\%). Waterfowl use of Klamath Basin National Wildlife Refuge (NWR) averaged $42 \%$ greater during spring 2002-2003 (568,500 bpd) than during 1998-2001 (Gilmer et al. 2004). Numerous factors likely impacted magnitude and distribution of waterfowl use of SONEC during spring, including weather, waterfowl populations, SONEC habitat, and species ecology. SONEC is a critical spring staging area for waterfowl that winter in the Central Valley of California and other Pacific Flyway regions and should be a major focus area for waterfowl-habitat conservation efforts.
\end{abstract}

Key words: waterfowl, spring migration, Klamath, Great Basin, Northern Pintail, Anas acuta.

The Klamath Basin and other areas in the southern Oregon, northeastern California, and extreme northwestern Nevada region (hereafter called SONEC; Fig. 1) of North America provide important habitat for waterfowl in the Pacific Flyway. Situated directly between California's Central Valley, the main wintering area for Pacific Flyway waterfowl, and major breeding areas in Alaska and the Prairie-Parklands (Bellrose 1980), SONEC is especially important during fall and spring migration. Spring habitats are especially critical for earlynesting species such as Northern Pintails (Anas acuta), a species of special concern because of their continued low populations (Miller and
Duncan 1999). Miller et al. (2005) reported that $77 \%-87 \%$ of female pintails equipped with satellite transmitters during late winter in the Central Valley of California visited SONEC in spring on their way north. However, abundance patterns of pintails in SONEC were not studied. Gilmer et al. (2004) reported abundance of all waterfowl on national wildlife refuges in the Klamath Basin but not for the bulk of the SONEC region. Most land in SONEC is privately owned and susceptible to change in management that could negatively impact its value to waterfowl. Competition for water supplies in the Klamath Basin is severe (Klamath Basin Crisis 2006, Klamath Tribal

${ }_{1}^{1}$ United States Geological Survey, Western Ecological Research Center, 6924 Tremont Road, Dixon, CA 95620. E-mail: joe_fleskes@usgs.gov

${ }^{2}$ United States Geological Survey, Western Ecological Research Center, 3020 State University Drive-East, Modoc Hall, Room 3006, Sacramento, CA 95819. 


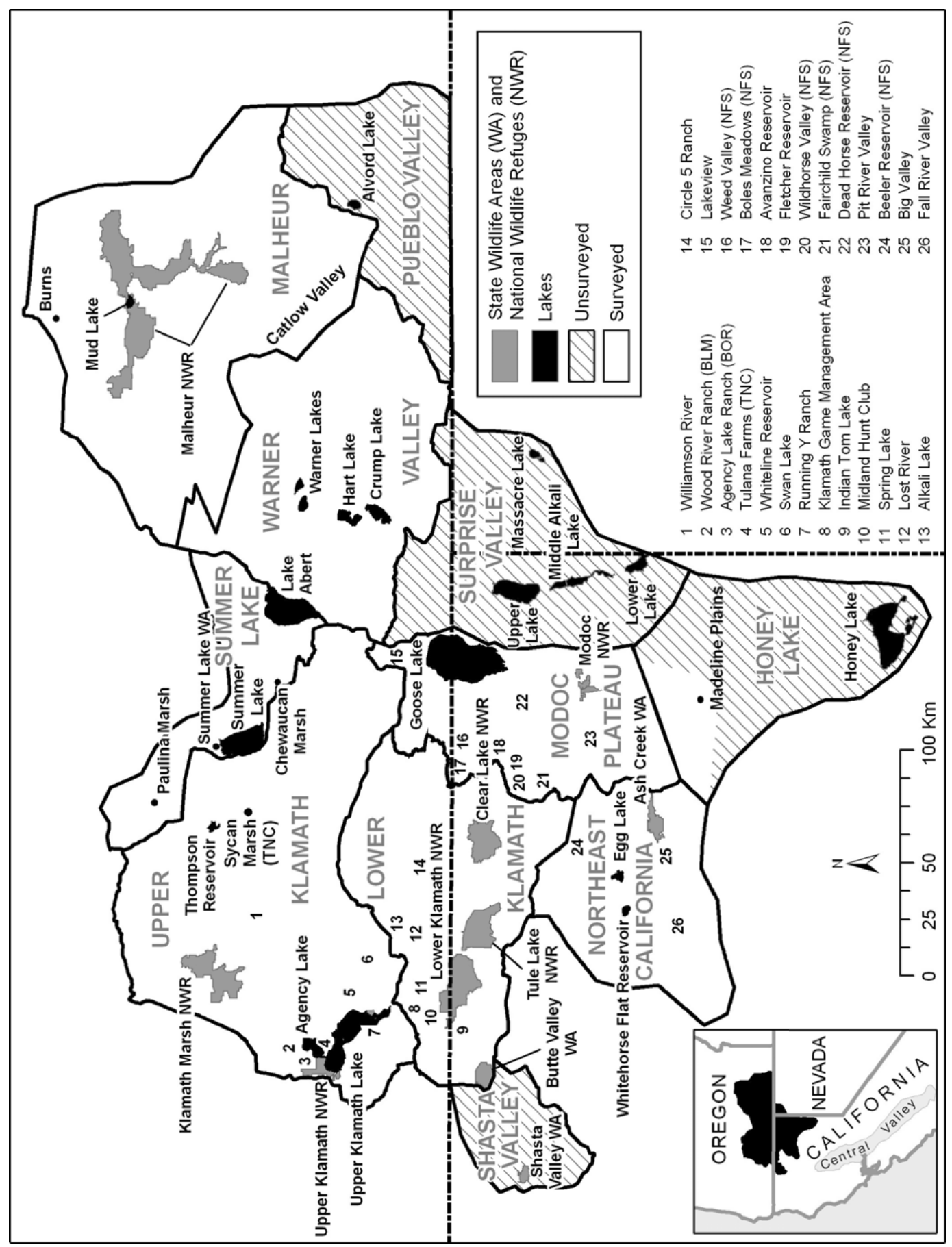


Council 2001) and, as in other western regions (United States Society for Irrigation and Drainage Professionals 2006), is increasing throughout SONEC. Redirection of water supplies could reduce area and quality of waterfowl habitats in SONEC. Wise allocation of limited water supplies in SONEC requires a thorough understanding of the needs of all water users, including migratory waterfowl. We studied abundance and distribution of waterfowl in SONEC during spring to quantify the importance of SONEC to waterfowl and to collect the data necessary to estimate waterfowl habitat requirements and guide conservation efforts in the region.

\section{StUdy AREA}

SONEC encompasses $70,491 \mathrm{~km}^{2}$ in the northwestern portion of the Great Basin (Hunt 1967) and includes all major wetland complexes in the intermountain reaches of southern Oregon, northeastern California, and extreme northwestern Nevada (Fig. 1). Extending up to $480 \mathrm{~km}$ east-west and $400 \mathrm{~km}$ north-south, SONEC has a basin and range topography with major uplift regions running predominantly north-south. Most waterfowl habitats are in basins between uplift regions, and the area of naturally flooded habitats and managed flooded habitats available for spring migrants is largely dependent upon the amount of spring rains and run-off from accumulated snow.

\section{SONEC Subregions Included in This Study}

The SONEC region was defined based upon spring locations of pintails tagged in California with satellite transmitters (PTTs) and upon the extent of wetland habitat (M.R. Miller, United States Geological Survey, personal communication; Miller et al. 2005). Originally, 7 SONEC subregions were identified based on roads and topographic features (Fleskes and Battaglia 2002), but 4 peripheral subregions were added to encompass a few new areas used by PTT-tagged pintails during the last years of that study (Fig. 1; Fleskes and Battaglia 2004). We surveyed waterfowl in the 7 original subregions and in the Madeline Plains part of the Honey Lake subregion (Fig. 1), which comprised $76 \%$ of SONEC's land area, and included $90 \%$ of SONEC's wetlands (Fleskes unpublished data) and $96 \%$ of the PTT-tagged pintail locations during 2002-2003 (Miller unpublished data).

Important waterfowl habitats are present in each SONEC subregion (Fig. 1). The Lower Klamath subregion includes Lower Klamath, Tule Lake, and Clear Lake National Wildlife Refuges (NWRs), Butte Valley State Wildlife Area (WA), Klamath River State Game Management Area, and numerous private-land habitats. The Upper Klamath subregion includes Upper Klamath and Klamath Marsh NWRs, Upper Klamath and Agency Lakes as well as adjacent federal, Nature Conservancy (TNC), and private habitats, and Sycan Marsh (TNC). The Modoc Plateau subregion includes Goose Lake, Modoc NWR, and numerous wetlands in Modoc National Forest. The Northeast California subregion includes Ash Creek WA, and habitats throughout Fall River and Big Valleys. The main habitats in the Warner Valley subregion are Hart Lake, Crump Lake, and other lakes and wetlands in Warner Valley. The Summer Lake subregion includes the Chewaucan Marsh, Summer Lake WA, and Lake Abert. The Malheur subregion includes the extensive Malheur NWR and habitats in both Catlow Valley and the Burns vicinity. The Honey Lake subregion includes Madeline Plains in the north (which we surveyed) and Honey Lake, with an associated WA and other habitats in the south (which we did not survey). The 3 subregions that we did not survey at all were Surprise Valley subregion, which contained the Lower, Middle, and Upper Lakes (usually dry) and wetlands in the Massacre Lake vicinity; Shasta Valley subregion with the Shasta Valley WA; and Pueblo Valley subregion, which contained Alvord Lake.

Fig. 1. Southern Oregon-northeastern California (SONEC) region comprised of 7 core subregions where waterfowl were surveyed from aircraft during 5 January-3 May 2002 and 2003, and 4 subregions (cross-hatched) that were added after this study began and, except for Madeline Plains, were not surveyed. Locations where waterfowl were regularly seen are shown for surveyed areas (BLM $=$ Bureau of Reclamation, BOR $=$ Bureau of Reclamation, $\mathrm{TNC}=$ The Nature Conservancy, NFS = National Forest Service), and major waterfowl habitats are shown in nonsurveyed areas (crosshatched). Surveyed areas comprised 76\% of SONEC's land area and included 90\% of SONEC's wetlands (Fleskes unpublished data) and $96 \%$ of the PTT-tagged pintail locations during the same period (Miller unpublished data). 


\section{Climate and Weather}

SONEC's complex topography results in highly variable and localized climate conditions, with some of the most extreme weather in California and Oregon (Western Regional Climate Center [Internet] [a, b]). Temperatures are highly variable throughout the year with summer maximums averaging $33^{\circ} \mathrm{C}\left(91^{\circ} \mathrm{F}\right)$ and winter minimums averaging $-7.2^{\circ} \mathrm{C}\left(19^{\circ} \mathrm{F}\right)$. As in most dry climates, daily temperatures vary widely, with rapid cooling after sunset leading to cold nights and rapid warming after sunrise leading to high daytime temperatures.

Weather conditions in SONEC during the study were similar to the long-term average. In 2002 the Standardized Precipitation Index (SPI) in the High Plateau and in the South Central Oregon climatic divisions that encompassed most of SONEC was near normal relative to the 109-year average for the 6 months (1 Aug 2001-31 Jan 2002) preceding spring, as well as for the core 3-month spring period (1 Feb-30 Apr 2002) and the entire 9-month period (1 Aug 2001-30 Apr 2002; Western Regional Climate Center [Internet] [d]). In 2003 the SPI was near normal for the 3- and 9-month periods ending on 30 April, but was moderately dry in both climatic divisions for the previous 6-month period (1 Aug 2002-31 Jan 2003). Spring temperatures were similar to long-term averages during both 2002 and 2003 for most SONEC sites with the exception of warmer-than-average January 2003 temperatures throughout SONEC and colderthan-average April 2003 temperatures in the western portion of SONEC (Western Regional Climate Center [Internet] [c], Fleskes and Battaglia 2004).

\section{Methods}

\section{Aerial Surveys}

United States Fish and Wildlife Service and Oregon Department of Fish and Game biologists who were familiar with the study area and who were experienced in surveying waterfowl from aircraft conducted 6 surveys of all major waterfowl habitat in the 7 core SONEC subregions during January-May in 2002 and 2003. Surveys were flown in single-engine, high-wing aircraft, $30-50 \mathrm{~m}$ above terrain, at a speed of 140-150 km $\cdot \mathrm{hr}^{-1}$. Two aircraft and crews were used to reduce survey duration and minimize likelihood of waterfowl move- ment among survey areas, which could lead to double counting. Jim Hainline, observing from the front right seat of an aircraft piloted by a contracted pilot, surveyed waterfowl in the Lower Klamath and Northeast California subregions, the southern part of the Upper Klamath and Modoc Plateau subregions, and Madeline Plains in the northern part of the Honey Lake subregion. Elizabeth Huggins, piloting and surveying from the left front seat, with Meg Laws or Marty St. Louis in the front right seat, surveyed waterfowl in the Warner Valley, Summer Lake, and Malheur subregions and in the northern parts of the Upper Klamath and Modoc Plateau subregions. Surveyors had $>10$ years (Huggins, Laws, and St. Louis) to $>30$ years (Hainline) of aerial waterfowl survey experience and training in species identification and estimation of flock sizes (e.g., 1 to $>10,000)$ encountered during spring surveys in the region. Where large habitat blocks occurred (e.g., on most NWRs), observers flew standardized, parallel transects, which were spaced $0.4 \mathrm{~km}$ apart for Hainline and $0.8 \mathrm{~km}$ apart for Huggins and Laws/St. Louis. Waterfowl within a $0.4-\mathrm{km}$ swath parallel to the aircraft track were counted off the right side (by Hainline) or off both the left (by Huggins) and right side (by Laws or St. Louis) of the aircraft. Small or linear habitats (e.g., reservoir shorelines, streams) were flown in a track that most efficiently surveyed the area. Large waterfowl concentrations were circled to obtain a complete count before the transect track was resumed. While flying, surveyors dictated estimated counts and locations on a voice recorder and later entered the information into a database. The estimated number of each waterfowl species (Table 1) seen by area (Fig. 1) and survey date (2002: 3-5 Jan, 21-22 Feb, 13-14 Mar, 27-28 Mar, 18-19 Apr, and 2-3 May; 2003: 5-6 Jan, 20-22 Feb, 12-18 Mar, 1-8 Apr, 14$18 \mathrm{Apr}$, and $30 \mathrm{Apr}-4$ May) were summarized.

\section{Data Analysis}

We plotted waterfowl abundance and calculated total use days and average birds per day (bpd) during the 119-day spring survey period (5 Jan-3 May) for each SONEC subregion (we included Madeline Plains in the Modoc Plateau total) and for the total surveyed areas (i.e., SONEC total). We also estimated use for protected areas (i.e., state management areas and WAs, federal lands [NWRs, 
TABLE 1. Abundance (average birds per day [bpd]) and species composition (\% of total) of waterfowl counted during aerial surveys in southern Oregon and northeastern California (SONEC) during 5 January-3 May 2002 and 2003.

\begin{tabular}{|c|c|c|c|c|c|c|}
\hline \multirow[b]{2}{*}{ Species or group } & \multicolumn{2}{|c|}{2002} & \multicolumn{2}{|c|}{2003} & \multicolumn{2}{|c|}{ 2002-2003 average } \\
\hline & bpd & $\%$ & bpd & $\%$ & bpd & $\%$ \\
\hline Dabbling ducks & 572,400 & 53.2 & 571,800 & 53.1 & 572,100 & 53.2 \\
\hline Northern Pintail & 275,200 & 25.6 & 263,800 & 24.5 & 269,500 & 25.0 \\
\hline Northern Shoveler & 93,500 & 8.7 & 118,400 & 11.0 & 108,900 & 9.8 \\
\hline American Wigeon & 97,100 & 9.0 & 64,000 & 5.9 & 80,600 & 7.5 \\
\hline Green-winged Teal & 58,900 & 5.5 & 81,600 & 7.6 & 70,200 & 6.5 \\
\hline Mallard & 31,600 & 2.9 & 22,500 & 2.1 & 27,100 & 2.5 \\
\hline Gadwall & 15,500 & 1.4 & 20,500 & 1.9 & 18,000 & 1.7 \\
\hline Cinnamon Teal & 700 & 0.1 & 1000 & 0.1 & 900 & 0.1 \\
\hline Wood Duck & 0 & 0 & 0 & 0 & 0 & 0 \\
\hline Diving ducks & 145,400 & 13.5 & 99,000 & 9.2 & 122,200 & 11.4 \\
\hline Ruddy Duck & 49,600 & 4.6 & 28,200 & 2.6 & 38,900 & 3.6 \\
\hline Scaup & 45,100 & 4.2 & 25,400 & 2.4 & 35,200 & 3.3 \\
\hline Bufflehead & 18,500 & 1.7 & 17,600 & 1.6 & 18,100 & 1.7 \\
\hline Canvasback & 17,400 & 1.6 & 17,200 & 1.3 & 14,200 & 1.3 \\
\hline Mergansers & 7800 & 0.7 & 7600 & 0.7 & 7700 & 0.7 \\
\hline Ring-necked Duck & 5800 & 0.5 & 5700 & 0.5 & 5800 & 0.5 \\
\hline Goldeneyes & 600 & 0.1 & 1800 & 0.2 & 1200 & 0.1 \\
\hline Redhead & 600 & 0.1 & 1700 & 0.2 & 1200 & 0.1 \\
\hline Geese & 265,000 & 24.6 & 315,800 & 29.3 & 290,400 & 27.0 \\
\hline \multicolumn{7}{|l|}{ Snow Goose and } \\
\hline Ross’s Goose & 122,300 & 11.4 & 172,300 & 16.0 & 147,300 & 13.7 \\
\hline \multicolumn{7}{|l|}{ White-fronted } \\
\hline Goose & 123,000 & 11.5 & 127,800 & 11.9 & 125,800 & 11.7 \\
\hline Canada Goose & 18,800 & 1.7 & 15,700 & 1.4 & 17,300 & 1.6 \\
\hline Tundra Swan & 29,800 & 2.8 & 20,200 & 1.9 & 25,000 & 2.3 \\
\hline American Coot & 62,900 & 5.8 & 69,500 & 6.4 & 66,200 & 6.2 \\
\hline ALL WATERFOWL & $1,075,400$ & 100.0 & $1,076,300$ & 100.0 & $1,075,900$ & 100.0 \\
\hline
\end{tabular}

Bureau of Reclamation, Bureau of Land Management, and USDA Forest Service] and private conservation organizations [i.e., TNC]) and for the Klamath Basin NWR complex. Use days, which were needed to determine regional habitat requirements (i.e., required hectares of habitat $=$ use days $\times$ daily energy required per individual waterfowl / energy provided per hectare of habitat), were calculated by assuming linear change in abundance between survey dates. We calculated average abundance (i.e., bpd) by dividing use days by 119 (number of days in our spring study period) to allow comparison of average abundance with other periods or areas. Because surveys required more than 1 day to complete and dates varied only slightly between years, we standardized the survey dates as 5 January, 21 February, 13 March, 30 March, 16 April, and 3 May to facilitate graphic comparison among years. To place results of our 2-year study in a longer time frame, we compared waterfowl abundance on the Klamath Basin NWR complex portion of
SONEC during our study with abundance reported for the same areas during 1998-2001 and 1953-2001 (Gilmer et al. 2004). We defined peak abundance in SONEC as the single maximum count (of a species or group of species) during any of the 6 surveys conducted during our 5 January-3 May spring study period. As a measure of the importance of SONEC as a Pacific Flyway waterfowl spring migration area, we compared peak abundance that we observed in SONEC during our 5 January-3 May spring study period to winter abundance reported during the annual late-Decemberearly January "midwinter" aerial survey for all of California plus the portion of Oregon (region 69-3) that includes SONEC (United States Fish and Wildlife Service 2002, 2003). We did not include waterfowl in more southern wintering areas (i.e., Mexico's west coast and Baja) in this comparison because (1) a significant portion of waterfowl that winter there are associated with other flyways (Bellrose 1980), (2) data for those areas were not available for both years of 

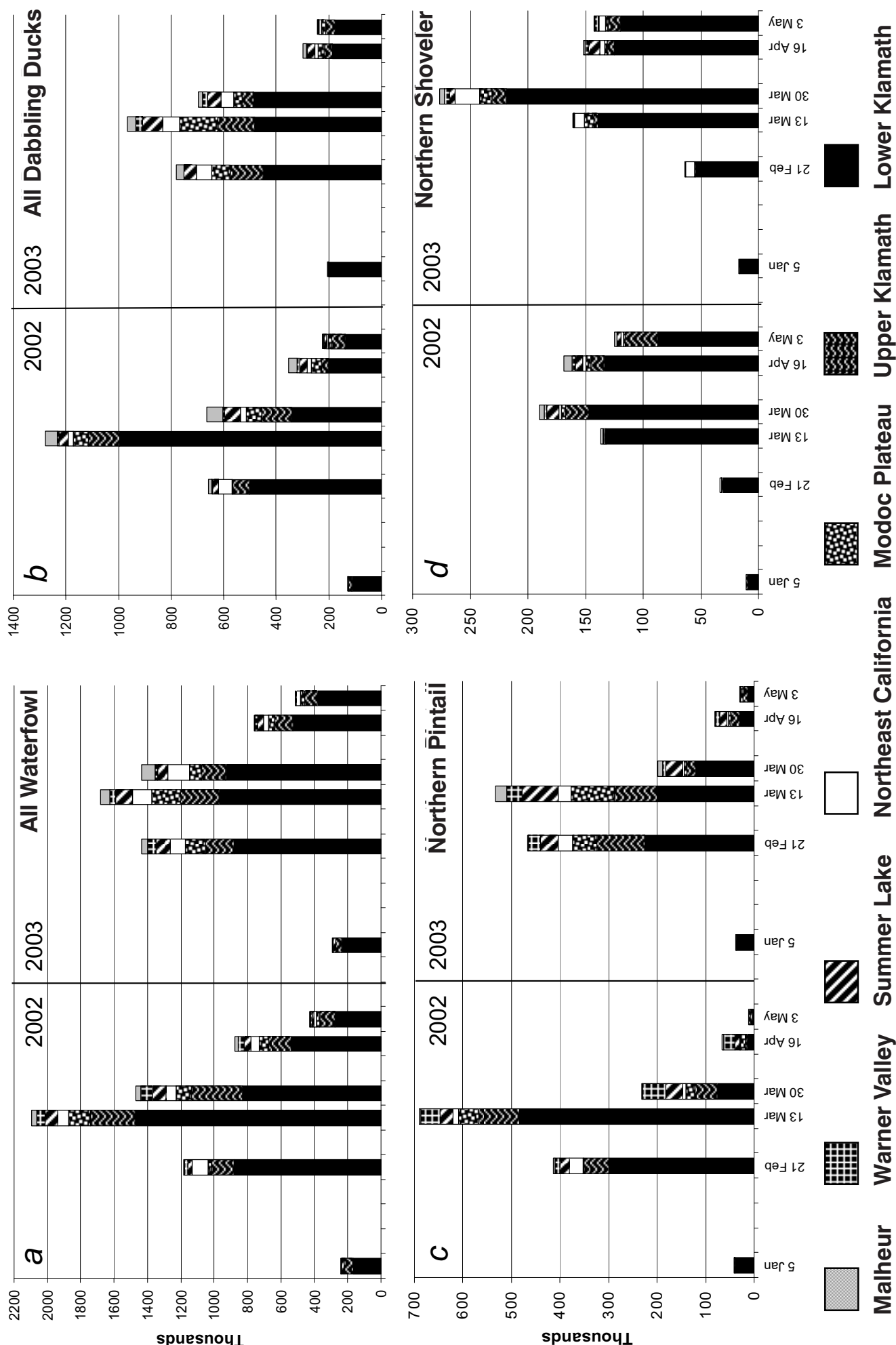

Fig. 2a-x. Abundance of waterfowl species or species groups in each southern Oregon-northeastern California Modoc Plateau total includes waterfowl counted in the adjacent Madeline Plains of the Honey Lake subregion $(<3 \%$ of 

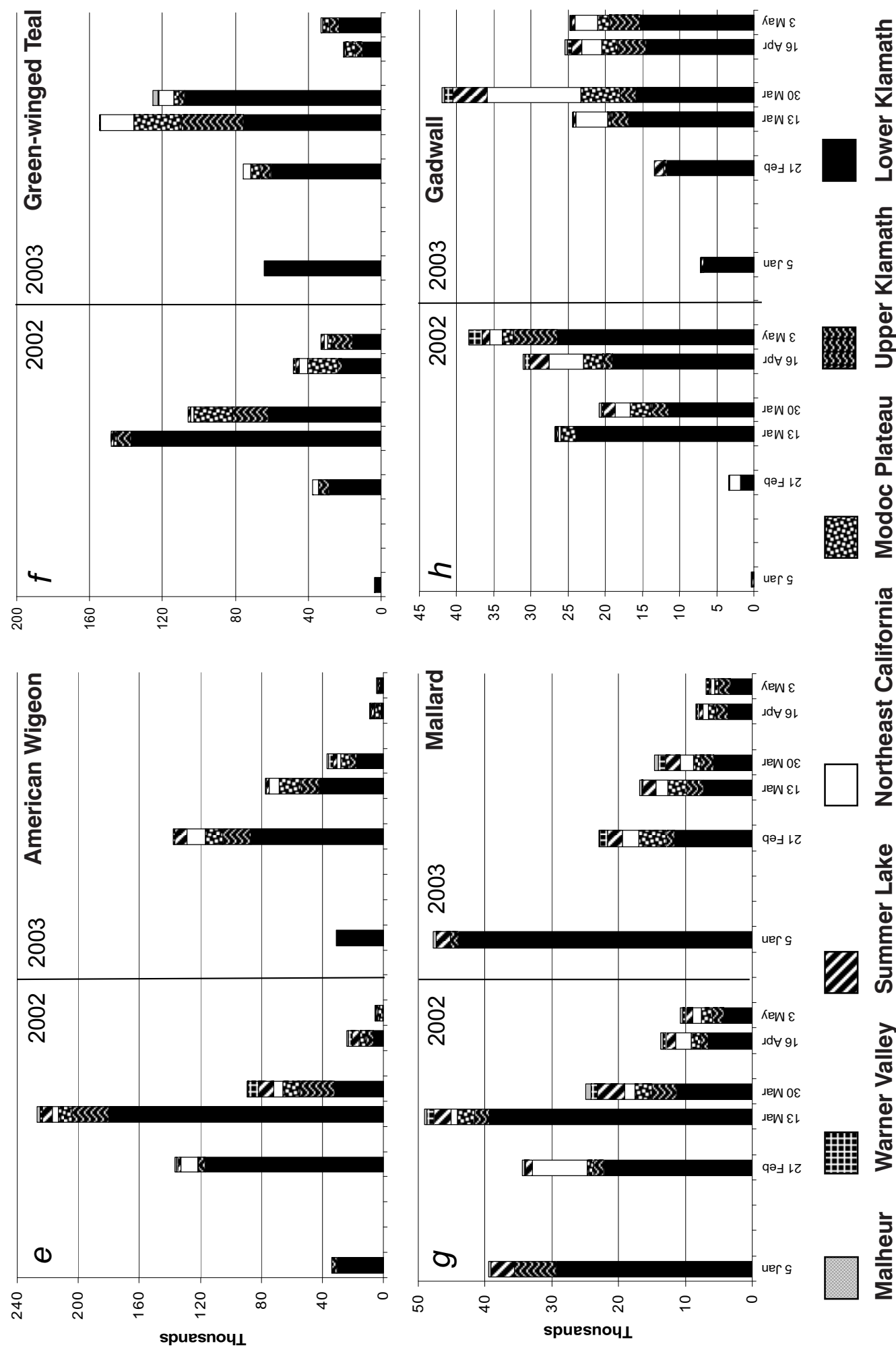

(SONEC) subregion on the dates when aerial surveys were conducted during 5 January-3 May 2002 and 2003. The the Modoc Plateau and Madeline Plains total). 

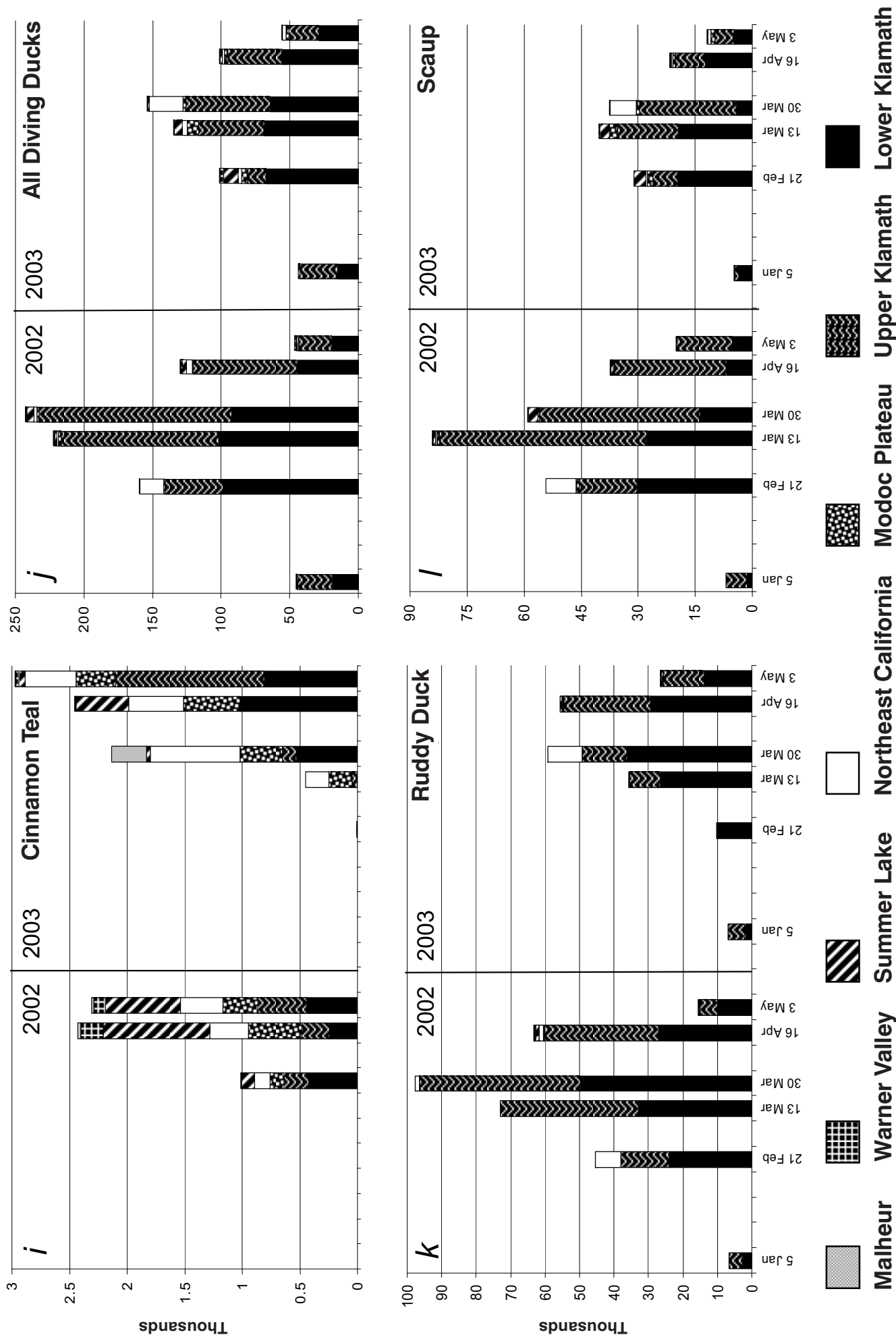

Fig. 2a-x. Continued. 

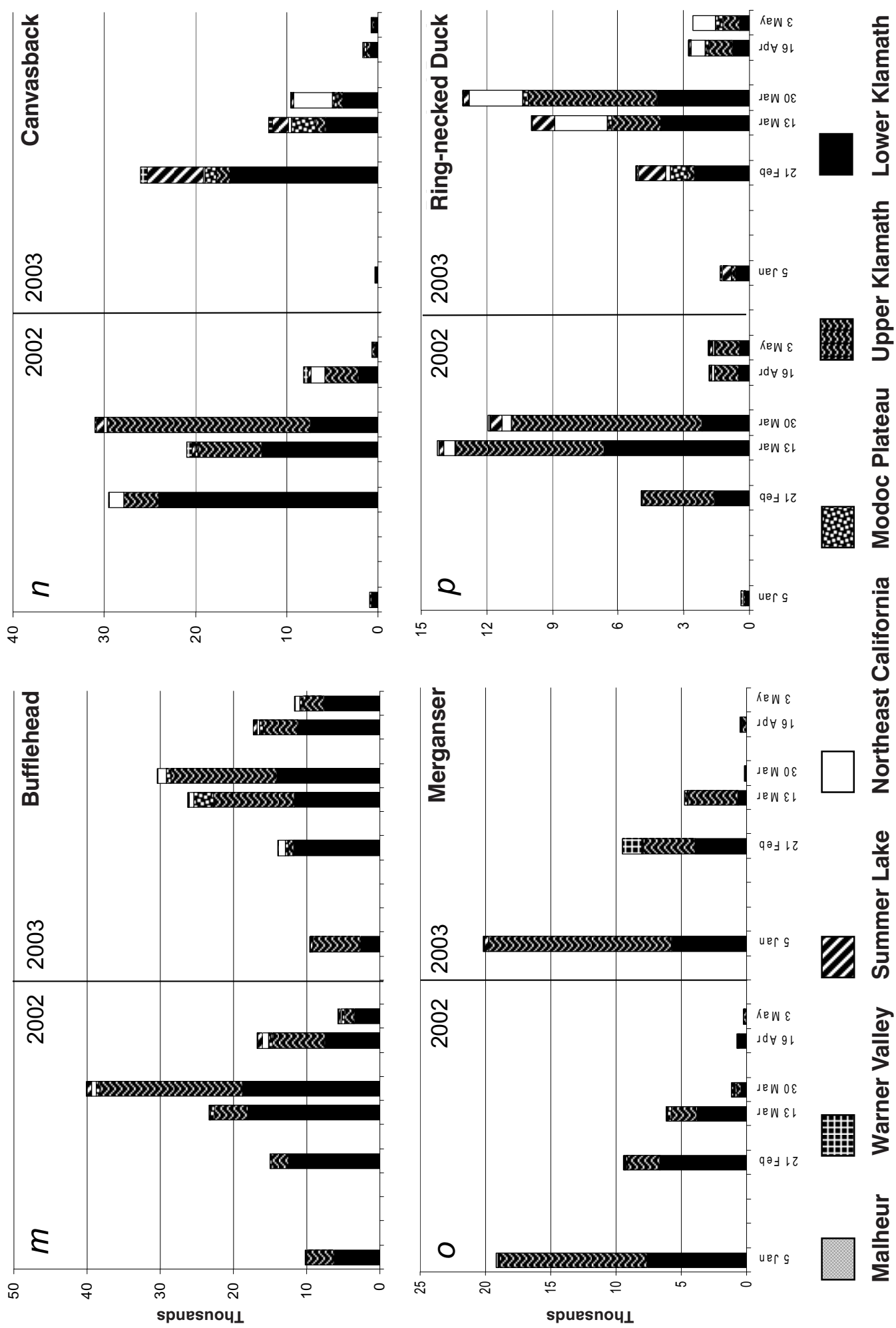

Fig. 2a-x. Continued. 

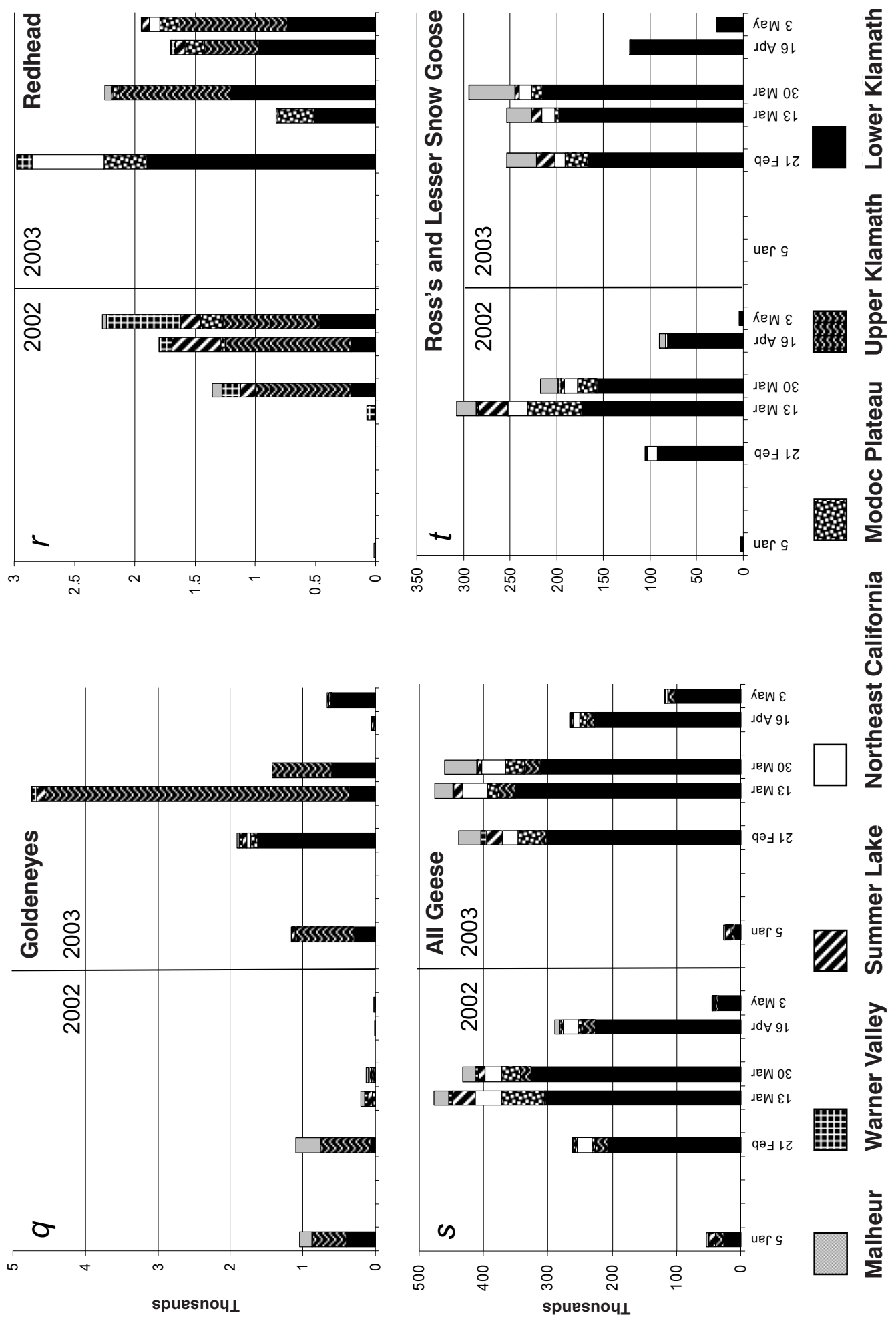

Fig. 2a-x. Continued. 

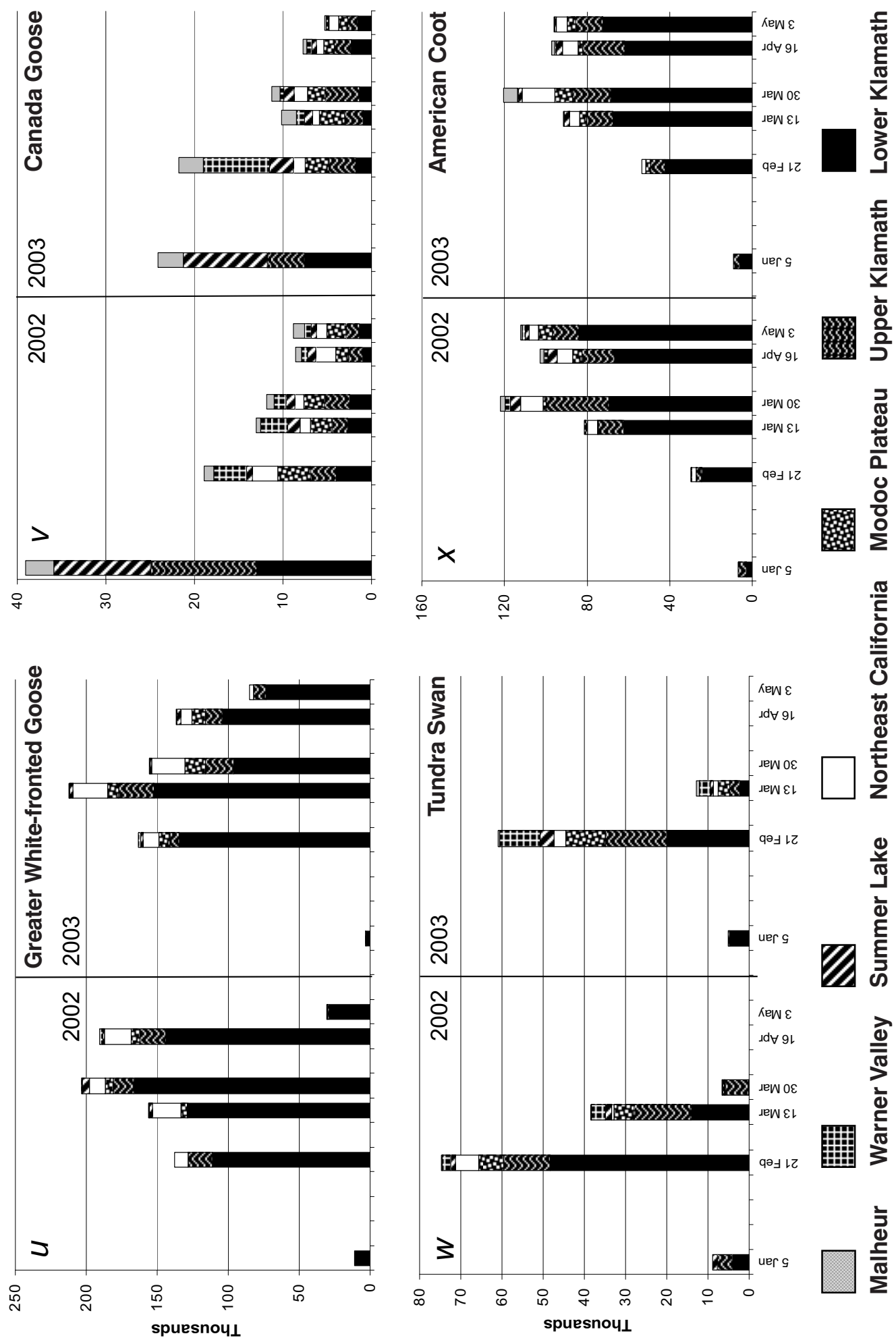

Fig. 2a-x. Continued. 
TABLE 2. Peak waterfowl abundance in southern Oregon and northeastern California (SONEC) during spring and as a percentage of midwinter abundance in all of California and Oregon survey area 69-3 during 2002 and 2003.

\begin{tabular}{|c|c|c|c|c|c|c|}
\hline \multirow[b]{2}{*}{ Species or group } & \multicolumn{2}{|c|}{2002} & \multicolumn{2}{|c|}{2003} & \multicolumn{2}{|c|}{$2002-2003$ average $^{a}$} \\
\hline & peak & $\%$ & peak & $\%$ & peak & $\%$ \\
\hline Dabbling ducks & $1,276,900$ & 54.2 & 966,700 & 38.1 & $1,121,800$ & 46.1 \\
\hline Northern Pintail & 689,300 & 74.3 & 532,100 & 53.9 & 610,700 & 64.1 \\
\hline Northern Shoveler & 189,900 & 45.1 & 276,800 & 82.5 & 233,400 & 63.8 \\
\hline American Wigeon & 227,100 & 56.7 & 137,700 & 30.5 & 182,400 & 43.1 \\
\hline Green-winged Teal & 148,100 & 73.6 & 154,600 & 46.2 & 151,300 & 59.9 \\
\hline Mallard & 49,100 & 19.2 & 47,800 & 15.8 & 48,500 & 17.5 \\
\hline Gadwall & 38,400 & 24.2 & 41,900 & 36.0 & 40,200 & 30.1 \\
\hline Cinnamon Teal & 2400 & 87.6 & 3000 & 36.4 & 2700 & 62.0 \\
\hline Wood Duck & 0 & 0 & 0 & 0 & 0 & 0 \\
\hline Diving ducks & 242,700 & 76.0 & 153,700 & 48.7 & 198,200 & 62.4 \\
\hline Ruddy Duck & 97,700 & 124.6 & 59,300 & 77.9 & 78,500 & 101.2 \\
\hline Scaup & 84,100 & 64.3 & 40,400 & 45.5 & 62,200 & 54.9 \\
\hline Bufflehead & 40,200 & 96.6 & 30,400 & 86.3 & 35,300 & 91.4 \\
\hline Canvasback & 31,000 & 183.5 & 26,100 & 45.4 & 28,600 & 114.4 \\
\hline Mergansers & 19,200 & 98.4 & 20,400 & 99.0 & 19,800 & 98.6 \\
\hline Ring-necked Duck & 14,300 & 53.3 & 13,100 & 41.7 & 13,700 & 47.5 \\
\hline Goldeneyes & 1100 & 23.7 & 4700 & 83.8 & 2900 & 53.8 \\
\hline Redhead & 2300 & 323.4 & 3000 & 250.0 & 2600 & 286.7 \\
\hline Geese & 476,700 & 80.3 & 476,000 & 66.9 & 476,400 & 73.6 \\
\hline \multicolumn{7}{|l|}{ Snow Goose and } \\
\hline Ross’s Goose & 307,700 & 90.5 & 293,300 & 73.3 & 300,500 & 81.9 \\
\hline White-fronted Goose & 203,100 & 107.2 & 212,000 & 83.9 & 207,500 & 95.6 \\
\hline Canada Goose & 19,100 & 61.2 & 24,200 & 41.3 & 31,650 & 51.3 \\
\hline Tundra Swan & 74,800 & 141.0 & 61,000 & 77.7 & 68,000 & 109.4 \\
\hline American Coot & 121,900 & 38.3 & 120,600 & 49.2 & 121,300 & 43.8 \\
\hline ALL WATERFOWL & $2,095,700$ & 57.3 & $1,681,700$ & 43.2 & $1,888,700$ & 50.3 \\
\hline
\end{tabular}

aBrant (Branta bernicla; 2002: 4092; 2003: 3124), scoters (Melanitta spp.; 2002: 28,722; 2003: 28,958), and unidentified ducks (2002: 20,199; 2003: 18,270 [nearly all in San Francisco Bay]) were present during midwinter surveys in California (United States Fish and Wildlife Service 2002, 2003) but were excluded from this comparison because none were seen in SONEC.

our study, and (3) in recent years when surveys were flown, waterfowl there comprised $<7 \%$ of Pacific Flyway totals (United States Fish and Wildlife Service 2000, 2003). We report use days, peak abundance, and bpd rounded to the nearest hundred.

\section{Results}

\section{Abundance and Species Composition}

Total waterfowl-use days (ducks, geese, swans, and coots) in SONEC during the 119day, 5 January-3 May spring period was similar during 2002 (127,977,700 use days) and 2003 (128,076,200 use days) and averaged $1,075,900$ bpd (Table 1). Waterfowl abundance peaked in mid-March in both years: 2,095,700 in 2002 and 1,681,700 in 2003 (Fig. 2a). Dabbling ducks accounted for $53.2 \%$ of the waterfowl use days with dabbler abundance also peaking in mid-March in both years (Table 1, Fig. 2b). Pintails were the most abundant dab- bler and waterfowl species in both years, accounting for $25.6 \%$ of the waterfowl-use days 2002 and $24.5 \%$ in $2003(\bar{x}=25.0 \%$; Table 1). Northern Pintail abundance also peaked during the 13 March survey: 689,300 in 2002 and 532,100 in 2003 (Table 2, Fig. 2c). All other dabbling ducks combined, including (in order of decreasing bpd, Table 1) Northern Shoveler (Anas clypeata), American Wigeon (Anas americana), Green-winged Teal (Anas crecca), Mallard (Anas platyrhynchos), Gadwall (Anas strepera), and Cinnamon Teal (Anas cyanoptera), accounted for $27.6 \%$ of the 2002 and $28.6 \%$ of the 2003 waterfowl-use days. Abundance of these non-pintail dabblers (Fig. $2 \mathrm{~d}-\mathrm{i})$ peaked at 587,600 in 2002 (13 Mar) and 498,100 in 2003 (30 Mar). Diving ducks, including (in order of decreasing bpd; Table 1) Ruddy Duck (Oxyura jamaicensis), scaup (Aythya affinis and Aythya marila), Bufflehead (Bucephala albeola), Canvasback (Aythya valisineria), mergansers (mostly Mergus merganser 
TABLE 3. Difference (and percentage change) between 2003 and 2002 in average birds per day and peak abundance of waterfowl in southern Oregon and northeastern California (SONEC) during spring (5 January-3 May); and winter waterfowl abundance reported by the United States Fish and Wildlife Service for all of California and Oregon survey area $69-3^{\mathrm{a}}$.

\begin{tabular}{lccc}
\hline Species or group & SONEC birds per day & SONEC peak abundance & Winter abundance \\
\hline Dabbling ducks & $-600(-0.1 \%)$ & $-310,200(-24.3 \%)$ & $+168,100(+7.1 \%)$ \\
Diving ducks & $-46,400(-31.9 \%)$ & $-89,000(-36.6 \%)$ & $-3,800(-1.2 \%)$ \\
Geese & $+50,800(+19.2 \%)$ & $-700(-0.1 \%)$ & $+117,800(+19.8 \%)$ \\
Tundra Swan & $-9,500(-32.1 \%)$ & $-13,800(-18.4 \%)$ & $+25,500(+48.0 \%)$ \\
American Coot & $+6,600(+10.5 \%)$ & $-1,300(-1.1 \%)$ & $-73,200(-23.0 \%)$ \\
ALL WATERFOwL & $+800(+0.08 \%)$ & $-415,000(-19.8 \%)$ & $+235,700(+6.5 \%)$ \\
\hline
\end{tabular}

aUnited States Fish and Wildlife Service 2002

bUnited States Fish and Wildlife Service 2003

and Lophodytes cucullatus but some Mergus serrator), Ring-necked Duck (Aythya collaris), goldeneyes (Bucephala clangul and Bucephala islandica), and Redhead (Aythya americana), accounted for $13.5 \%$ of the 2002 and $9.2 \%$ of the 2003 waterfowl-use days (Table 1). Diving duck abundance peaked at 242,700 in 2002 (30 Mar) and 153,700 in 2003 (30 Mar; Table 2, Fig. 2j-r). White geese (Ross's Goose [Chen rossii] and Lesser Snow Goose [Chen caerulescens]), Greater White-fronted Geese (Anser albifrons), and Canada Geese (Branta canadensis) accounted for $24.6 \%$ of the 2002 and $29.3 \%$ of the 2003 waterfowl-use days. Goose abundance peaked at 476,700 in 2002 and at 476,000 in 2003 in March for all geese combined, white geese, and White-fronted Geese, but in January for Canada Geese (Figs. 2s-v). Tundra Swans (Cygnus columbianus) accounted for $2.8 \%$ of the 2002 and $1.9 \%$ of the 2003 waterfowl-use days with peak abundance of 74,800 in 2002 and 61,000 in 2003 (Fig. 2w). American Coots (Fulica americana) accounted for $5.8 \%$ of the 2002 and $6.4 \%$ of the 2003 waterfowl-use days with peak abundance of 121,900 in 2002 and 120,600 in 2003 (Fig. 2x).

Although total waterfowl-use days during 2003 changed little $(+0.08 \%)$ from 2002 , abundance of some species differed among years (Table 1). Dabbling duck-use days in 2003 were nearly identical $(-0.1 \%)$ to those in 2002 , but diving duck use was down $32 \%$ and goose use was up 19\%. Abundance varied more between years for individual species than for species groups. Use days were higher in 2003 than in 2002 for Northern Shoveler $(+27 \%)$, Green-winged Teal $(+39 \%)$, Gadwall $(+33 \%)$, Cinnamon Teal $(+43 \%)$, Goldeneyes $(+209 \%)$, Redhead $(+164 \%)$, white geese
$(+41 \%)$, Greater White-fronted Goose $(+3 \%)$, and American Coot $(+10 \%)$. Use days were lower in 2003 than in 2002 for Northern Pintail $(-4 \%)$, American Wigeon $(-34 \%)$, Mallard $(-29 \%)$, Ruddy Duck $(-43 \%)$, scaup $(-44 \%)$, Bufflehead (-5\%), Canvasback (-37\%), mergansers $(-2 \%)$, Ring-necked Duck $(-1 \%)$, Canada Goose $(-16 \%)$, and Tundra Swan $(-32 \%)$.

\section{Percentage of Winter Population Using SONEC During Spring}

A large proportion of waterfowl that wintered in California and southern Oregon used SONEC during the spring migration period. Peak spring abundance in SONEC during 2002 and 2003 averaged 50.3\% of the midwinter abundance in California and Oregon survey region $69-3$ for all waterfowl, $46.1 \%$ for dabbling ducks, $62.4 \%$ for diving ducks, $68.8 \%$ for geese, $109.4 \%$ for swans, and $43.8 \%$ for coots (Table 2). Peak spring abundance of pintails in SONEC averaged $64.1 \%$ of their midwinter abundance in California and southern Oregon. A lower percentage of wintering Mallard $(17.5 \%)$ and Gadwall $(30.1 \%)$ than other dabblers (43.6\%-64.1\%) and a lower percentage of Canada Goose (51.3\%) than other geese (81.9-95.6\%) used SONEC during spring (Table 2). A greater percentage of the wintering Bufflehead (91.4\%), mergansers (98.6\%), Ruddy Duck (101.2\%), Canvasback (114.4\%), and Redhead (286.7\%) than other diving ducks (47.4\%-54.9\%) used SONEC during spring.

Midwinter waterfowl abundance in California and southern Oregon in 2003 was 6.5\% greater than in 2002 , but peak spring waterfowl abundance in SONEC in 2003 was $19.8 \%$ lower than in 2002 (Table 3). Thus, SONEC peak spring abundance represented a lower 
TABLE 4. Total waterfowl-use days for all of the southern Oregon and northeastern California (SONEC) study region and distribution of use days among SONEC subregions during 5 January-3 May (2002-2003 average).

\begin{tabular}{|c|c|c|c|c|c|c|c|c|}
\hline \multirow[b]{2}{*}{ Species or group } & \multirow[b]{2}{*}{ Total use days } & \multicolumn{7}{|c|}{ Distribution of use days among subregions (\%) } \\
\hline & & $\begin{array}{c}\text { Lower } \\
\text { Klamath }\end{array}$ & $\begin{array}{c}\text { Upper } \\
\text { Klamath }\end{array}$ & $\begin{array}{l}\text { Northeast } \\
\text { California }\end{array}$ & $\begin{array}{l}\text { Modoc } \\
\text { Plateau }^{\mathrm{a}}\end{array}$ & $\begin{array}{l}\text { Summer } \\
\text { Lake }\end{array}$ & $\begin{array}{c}\text { Warner } \\
\text { Valley }\end{array}$ & Malheur \\
\hline Dabbling ducks & $68,077,400$ & 66 & 12 & 5 & 7 & 6 & 4 & 1 \\
\hline Northern Pintail & $32,068,600$ & 57 & 15 & 4 & 8 & 8 & 6 & 1 \\
\hline Northern Shoveler & $12,606,200$ & 84 & 4 & 4 & 2 & 3 & $<1$ & 1 \\
\hline American Wigeon & $9,586,900$ & 71 & 10 & 6 & 7 & 4 & 2 & $<1$ \\
\hline Green-winged Teal & $8,355,100$ & 74 & 11 & 5 & 9 & $<1$ & $<1$ & $<1$ \\
\hline Mallard & $3,222,800$ & 67 & 8 & 8 & 6 & 7 & 2 & 1 \\
\hline Gadwall & $2,141,600$ & 66 & 6 & 13 & 7 & 6 & 2 & $<1$ \\
\hline Cinnamon Teal & 96,300 & 26 & 13 & 21 & 18 & 17 & 2 & 3 \\
\hline Wood Duck & 0 & - & - & - & - & - & - & - \\
\hline Diving ducks & $14,538,500$ & 49 & 41 & 4 & 2 & 3 & 1 & 1 \\
\hline Ruddy Duck & $4,633,600$ & 54 & 41 & 5 & $<1$ & $<1$ & $<1$ & $<1$ \\
\hline Scaup & $4,192,700$ & 40 & 49 & 5 & 2 & 3 & $<1$ & $<1$ \\
\hline Bufflehead & $2,148,400$ & 60 & 34 & 2 & 3 & 1 & $<1$ & $<1$ \\
\hline Canvasback & $1,687,200$ & 58 & 24 & 5 & 3 & 8 & 2 & $<1$ \\
\hline Mergansers & 912,400 & 42 & 52 & $<1$ & 1 & 1 & 3 & $<1$ \\
\hline Ring-necked Duck & 687,100 & 36 & 44 & 10 & 3 & 7 & $<1$ & $<1$ \\
\hline Goldeneyes & 139,500 & 34 & 53 & $<1$ & 2 & 3 & 1 & 7 \\
\hline Redhead & 137,700 & 46 & 26 & 8 & 9 & 5 & 6 & 1 \\
\hline Geese & $34,558,100$ & 72 & 5 & 7 & 6 & 4 & 1 & 5 \\
\hline \multicolumn{9}{|l|}{ Snow Goose and } \\
\hline Ross’s Goose & $17,531,600$ & 73 & $<1$ & 5 & 8 & 5 & $<1$ & 9 \\
\hline \multicolumn{9}{|l|}{ White-fronted } \\
\hline Goose & $14,973,200$ & 79 & 7 & 9 & 4 & 1 & $<1$ & $<1$ \\
\hline Canada Goose & $2,053,200$ & 23 & 20 & 7 & 11 & 17 & 12 & 9 \\
\hline Tundra Swan & $2,974,170$ & 48 & 22 & 5 & 11 & 4 & 9 & $<1$ \\
\hline American Coot & $7,878,900$ & 69 & 16 & 7 & 3 & 2 & 1 & 1 \\
\hline ALL WATERFOWL & $128,027,000$ & 66 & 14 & 6 & 6 & 4 & 3 & 2 \\
\hline
\end{tabular}

Madeline Plains accounted for $<3 \%$ of waterfowl use on Modoc Plateau and Madeline Plains combined.

percentage of wintering waterfowl abundance in 2003 than in 2002 (43.2\% vs. $57.3 \%$, Table 2 ). This trend was consistent for all species except Northern Shoveler, Gadwall, goldeneyes, mergansers, Canada Goose, and American Coot (Table 2). Neither waterfowl bpd nor peak abundance in SONEC during spring closely tracked changes in wintering waterfowl abundance in California and southern Oregon (Table 3).

\section{Temporal Abundance Patterns}

Except for a greater mid-March peak in 2002 than in 2003, the temporal pattern of waterfowl abundance in SONEC overall was similar in both years (Fig. 2a). Waterfowl abundance peaked during mid- or late March in all subregions in both years, except for in the Northeast California subregion in 2002 and the Warner Valley subregion in 2003, where abundance peaked during the late-February survey.
Abundance patterns in SONEC varied among species (Fig. 2a-x). Abundance of swans peaked (21 Feb) and declined earlier than abundance of other waterfowl. Abundance peaked during late February to late March and then declined for most other migrants, including pintails, Green-winged Teal, American Wigeon, Canvasback, scaup, Ring-necked Duck, Bufflehead, Ruddy Duck, goldeneyes, white geese, and Greater White-fronted Geese. Greater White-fronted Geese remained abundant in SONEC later than white geese. Abundance of Northern Shovelers, Gadwall, Cinnamon Teal, Redheads, and American Coots peaked (in 1 or both years) and was maintained later than abundance for other waterfowl species. Mallards, mergansers, and Canada Geese were as or more abundant in SONEC during the early January survey than during any later survey. 
Distribution Among

SONEC Subregions

Waterfowl distribution was similar in both years, with most use in the Lower (66\%) and Upper (14\%) Klamath subregions; 2\%-6\% occurred in each of the other subregions (Table 4). Distribution of dabbling ducks and coots among subregions was similar to the overall distribution of waterfowl (Table 4). However, diving duck use was much greater in the Upper Klamath subregion and resulted in a relatively even split of diving duck use between the Upper and Lower Klamath subregions. In contrast, goose use was slightly more concentrated in the Lower Klamath subregion than was dabbling duck use and coot use. Swan use, though occurring mostly in the Lower Klamath subregion (similar to use by other waterfowl groups), was more evenly distributed among subregions than other waterfowl use. Distribution of most species was similar to their species group except that both Cinnamon Teal and Canada Goose were much more evenly distributed among subregions than other species within their group (Table 4). Distribution among subregions also varied somewhat among survey dates. For instance, although the Lower Klamath subregion was overall the single most important subregion for most dabbling duck species, during late spring other subregions supported up to $95 \%$ of the American Wigeon and $78 \%$ of the Northern Pintail in SONEC (Fig. 2b-i). Thus, although the Lower Klamath subregion received the greatest overall waterfowl use, all subregions were important to 1 or more species during part of the spring (Fig. 2a-x).

\section{Distribution by Ownership}

Each spring, $75 \%$ of all waterfowl use in SONEC occurred on protected areas. A higher percentage of American Coot (81.5\%), dabbling ducks $(80.5 \%)$, and geese $(70.5 \%)$ were on protected areas than diving ducks $(60.4 \%)$ and swans (49\%). Among dabbling ducks, the percentage was lowest for Cinnamon Teal (61.8\%) and Northern Pintail (74.7\%) and highest for Northern Shoveler $(88.5 \%)$ and Green-winged Teal (91.9\%), with $76.4 \%-81.1 \%$ of the use of other dabblers on protected areas. Among diving ducks, the percentage was lowest for mergansers $(35.1 \%)$, goldeneyes $(43.8 \%)$, and scaup (55.5\%), and highest for Canvasback $(78.2 \%)$, with $59.2 \%-70.8 \%$ of the use of other divers on protected areas. Only $42.7 \%$ of Canada Geese were on protected areas compared to $71 \%$ of White-fronted Geese and $73.4 \%$ of white geese. The difference between the 2002 and 2003 percentage on protected areas was $<10 \%$ for geese, swans, coots, and all dabblers except Cinnamon Teal (2002: 47\%, 2003: 72.1\%; difference: $25.1 \%$ ). However, the 2003 percentage on protected areas was $>10 \%$ higher than the 2002 percentage for Ruddy duck (2002: $55.2 \%$; 2003: 66.3\%), scaup (2002: 49.7\%; 2003: 66.0\%), and Ring-necked Duck (2002: $63.8 \% ; 2003: 76.5 \%)$, and $>10 \%$ lower than the 2002 percentage for mergansers (2002: $46.5 \%$; 2003: $23.5 \%$ ).

The percentage of waterfowl counted on protected areas varied greatly among subregions. Most waterfowl use in Lower Klamath (87.8\%), Malheur (74.4\%), Modoc Plateau (64.6\%), and Upper Klamath (64.2\%), and some waterfowl use in Summer Lake (34.5\%) and Northeastern California $(27.3 \%)$ occurred on protected areas; however, none of the waterfowl use in the Warner Valley subregion occurred on protected areas.

\section{Abundance on Klamath Basin NWR: 2002-2003 vs. 1953-2001}

Spring waterfowl abundance (bpd) on the Klamath Basin NWR complex within SONEC during 2002-2003 (568,500 bpd) averaged $42 \%$ greater than during 1998-2001 (Gilmer et al. 2004) and 58.3\% greater than during 19532001 (Gilmer et al. 2004); however, the difference varied among species groups. Abundance during 2002-2003 compared to 1998-2001 and $1953-2001$ was $56.4 \%$ and $66.1 \%$ greater for dabbling ducks, $4.5 \%$ and $44.1 \%$ greater for diving ducks, $19.9 \%$ and $37.5 \%$ greater for geese, $64.1 \%$ and $100 \%$ greater for coots, and $12.6 \%$ and $77.5 \%$ greater for swans, respectively. Change in abundance of individual species varied much more than for species groups. Similar to the result for species groups, the abundance of most species during 2002-2003 was greater than it was during earlier periods. However, abundance during 2002-2003 was lower than during both 1998-2001 and 19532001 for Mallard $(-20.6 \%,-31.8 \%)$, Redhead $(-18.4 \%,-54.9 \%)$ and Canada Goose $(-33.7 \%$, $-76 \%)$ and lower than during 1998-2001 for Ruddy Duck (-11.3\%) and Ring-necked Duck $(-16.4 \%)$. 


\section{Discussion}

\section{Importance of SONEC to Waterfowl}

SONEC provides critical spring habitat to a majority of waterfowl that winter in California and southern Oregon. Estimated peak waterfowl abundance in SONEC during spring 2002 and 2003 averaged $50.3 \%$ of the midwinter waterfowl abundance in California (all survey regions) and southern Oregon (69-3 survey region). Northern Pintail, a species of special concern, was the most common species that used SONEC. Estimated peak spring abundance of pintails in SONEC was $64.1 \%$ of their winter abundance in California and southern Oregon, which was even greater than most other species. Further, we did not adjust our peak spring abundance estimates for SONEC areas that we did not survey, and we did not account for the many individuals that migrated through the region before or after the peak. Also, true peak abundance may have occurred on a date that we did not survey. Thus, our measure of peak abundance provides only a minimal estimate of the true percentage of the wintering waterfowl population that used SONEC.

\section{Potential Factors Impacting Waterfowl Use of SONEC}

A variety of factors including weather, waterfowl population size, available habitat, and each species' ecology likely influenced the magnitude, timing, and distribution of waterfowl use in SONEC during spring. Although additional research is needed to better determine the importance of each factor, a discussion of the general relationship between each factor and waterfowl use, which was indicated by our data, may be informative for resource managers.

WEATHER.-Waterfowl use (total and average bpd) was similar in both spring seasons, but peak abundance was about $25 \%$ higher in 2002 than in 2003 (Fig. 2a). Weather conditions within SONEC were near average in both years and do not explain the slightly different patterns of waterfowl abundance during 2002 and 2003. However, record cold prevailed to the north of SONEC during spring 2002 (see Miller et al. 2005). We speculate that frozen habitats to the north of SONEC prevented early migrants from leaving SONEC during 2002, resulting in an aggregation of both early and later migrants in SONEC and greater peak abundance.

SIZE OF WINTERING POPULATION.-Neither waterfowl use (total or bpd) nor peak abundance in SONEC during spring 2002 and 2003 closely tracked the changes in waterfowl abundance in California and Oregon wintering areas (Table 3). Gilmer et al. (2004) also reported that only a small portion of annual variability in spring waterfowl use of the Klamath Basin NWR complex portion of SONEC during 1953-1976 $\left(r^{2}=0.00, P=0.85\right)$ and 1977-2001 $\left(r^{2}=0.21, P=0.02\right)$ was explained by changes in midwinter waterfowl abundance, and they suggested that survey imprecision could explain the poor tracking. Thus, existing information indicates that the wintering population size does not have a large influence on waterfowl use or peak abundance in SONEC during spring, although more precise surveys are needed to better determine the relationship.

CARRying CAPACITY OF THE SONEC LANDSCAPE.-Our finding that the total number of waterfowl-use days in SONEC in 2003 was only $0.08 \%$ greater than in 2002 , while wintering abundance was $6.5 \%$ greater, suggests that under average environmental conditions (as occurred during our study), the SONEC landscape may be able to support no more than about 128 million waterfowl-use days during spring. However, the difference in the annual change of spring and winter waterfowl abundance that we observed was not great and was probably well within the precision of winter and spring surveys. Also, wider variation in annual precipitation than during our study could result in greater annual variation in the carrying capacity than what we observed. Our data suggest that a program to improve waterfowl habitat conditions in SONEC may be needed to ensure adequate migration habitat for waterfowl populations larger than those that occurred during our study or in years when precipitation in SONEC is below average; however, further study is needed.

Distribution of SONEC habitats.-Juxtaposition of subregions and amount of waterfowl habitat within each subregion influenced the distribution of waterfowl spring use in SONEC. The Lower Klamath subregion 
included several major NWRs and WAs, had more waterfowl habitat than most other subregions (Fleskes unpublished data), and was 1 of the 1st subregions in the direct pathway of waterfowl migration from the Central Valley (Fig. 1). Thus, it is not surprising that $66 \%$ of the waterfowl use occurred there.

There is some evidence that changing management may be altering distribution of SONEC habitat and shifting some waterfowl use from private to public areas. Spring waterfowl abundance (bpd) on the Klamath Basin NWR complex portion of SONEC during our study was $42 \%$ greater than during even the most recent period studied (1998-2001; Gilmer et al. 2004). We do not believe that this surprisingly large increase in waterfowl use on Klamath Basin NWR since 2001 was due to any changes in survey methods or observers; the same experienced biologist flew the same route to survey the Klamath Basin NWR complex portion of SONEC during both 1998-2001 and 2002-2003. Also, this large increase in spring waterfowl use of the Klamath Basin NWR was likely not due to any increase in spring waterfowl abundance throughout SONEC; midwinter waterfowl populations averaged $22 \%$ lower during 2002-2003 than during 19982001, and although the relationship between waterfowl abundance in SONEC during spring and waterfowl abundance on the wintering grounds is weak, smaller wintering populations would not be expected to result in greatly increased spring abundance throughout SONEC. Gilmer et al. (2004) reported that spring waterfowl abundance on the Klamath Basin NWR complex increased at a rate of about $11.6 \%$ per year during the 1990s. Thus, increased use of Klamath Basin NWR during our study period may have been a continuation of this increasing use. Abundance on the Klamath Basin NWR complex during our study period was still $20 \%$ greater than would be expected if the same $11.6 \%$ annual rate of increase had continued up through 2003. We speculate that enhanced management of spring habitats on at least some public areas (e.g., rotational wetland program on Tule Lake NWR [University of California, Santa Cruz 1996]; spring habitat flooding on Lower Klamath NWR [United States Fish and Wildlife Service, Internet]; and wetland restoration around Upper Klamath Lake [Oregon Habitat Joint Venture 2005]), perhaps combined with unchanging or reduced availability of habitat on private lands, may have shifted some waterfowl use in spring from private to public areas.

Species ECOLOGY.-Ecology of species impacted their use of SONEC. Differences in spring habitat preferences influenced species distribution patterns throughout SONEC. As for all waterfowl combined, $66 \%$ of dabbling duck use occurred in the Lower Klamath subregion. However, goose use was even more concentrated in the Lower Klamath, probably because this subregion contained not only the most wetlands but also the most cropland (Fleskes unpublished data). Although some species of dabbling ducks will feed in dry cropland as well as flooded cropland, geese feed more commonly in dry cropland than other waterfowl. Diving ducks differed from dabblers in having much greater use of the Upper Klamath subregion, probably because this subregion had the most permanent marsh (Fleskes unpublished data), a habitat most utilized by divers (Bellrose 1980). Although the Lower Klamath subregion received the greatest overall waterfowl use, all subregions were important to 1 or more species during part of the spring, reflecting the migration patterns of waterfowl and the dynamic nature of SONEC habitats during spring.

A species' use of SONEC during spring also reflected its breeding ecology. A lower percentage of the wintering population of Mallard, Gadwall, and Cinnamon Teal used SONEC during spring than other dabbling ducks. Canada Geese showed the same pattern in relation to other geese. In addition, we did not record Wood Duck (Aix sponsa) in SONEC during our surveys. Mallard, Gadwall, Cinnamon Teal, and Wood Duck are the most common duck species nesting in California (Anderson 1957, 1960, Bellrose 1980, Hothem and Welsh 1994, Trost and Drut 2004), and the Canada Goose is the only goose that commonly nests in California (Naylor 1953). Thus, a lower percentage of the wintering populations of these California-nesting species would be expected to migrate through SONEC than the percentage of northern-nesting species.

Location and timing of nesting also impacted migration patterns for species that nested primarily north of SONEC. Swans nest early in spring and mostly far north in Yukon and 
Alaska (Bellrose 1980). This nesting behavior accounts for their early migration through SONEC. Spring abundance of Northern Pintail, Green-winged Teal, American Wigeon, Canvasback, scaup, Ring-necked Duck, Bufflehead, and goldeneyes, all of which nest relatively early but primarily in the prairie-parklands, peaked slightly later than swans. Whitefronted Geese remained abundant in SONEC later than white geese. White-fronted Geese migrate directly over-ocean to their main Alaskan nesting area (Bellrose 1980). Their extended stay in SONEC probably allowed time for them to accumulate fat reserves for the long over-ocean migration (Lindstrom 2003) and increased the likelihood that conditions in Alaska were favorable when they arrived. The abundance of Northern Shoveler, Gadwall, Cinnamon Teal, Redhead, and American Coot peaked and was maintained later than abundance of other waterfowl species. Thus, these species either nest in significant numbers in SONEC or are late nesters elsewhere (Bellrose 1980). Mallard and Canada Goose were as or more abundant in SONEC during the January "midwinter" survey than during any spring survey, reflecting that many of these birds nest locally, and like mergansers, they tend to winter as far north as conditions allow.

Peak counts of a few species during spring in SONEC approximately equaled (e.g., mergansers 98.6\%, Ruddy Duck 101\%, swan 109\%, Canvasback 114\%) or were much greater (e.g., Redhead 237\%) than their wintering counts in California and Oregon. All these species commonly use open water habitats, occur in large groups, and are highly visible; swans and Canvasbacks also are completely or partially white. Thus, few of these species were probably missed during spring or winter surveys, and the high percentages indicate that nearly all those wintering in California and Oregon migrated through SONEC in spring. About $70 \%$ of Pacific Flyway Redheads winter in Mexico, a much higher percentage than for other waterfowl species (Bellrose 1980). Thus, many Redheads that migrated through SONEC likely wintered in Mexico and were not counted in California during the midwinter survey. In contrast, Wood Ducks, which were not recorded in SONEC during our surveys, commonly roost under trees or other cover in marshes, and are rarely counted during aerial surveys.

\section{Coverage and Reliability of Aerial Waterfowl Surveys}

Areas that we did not survey contained about $10 \%$ of SONEC's wetlands (Fleskes unpublished data) but were used by only $4 \%$ of PTT-tagged pintails during our study (Miller unpublished data). Thus, assuming that the distribution of other waterfowl was similar to pintails (as Table 4 indicates) and reflected wetland distribution, our estimate of total waterfowl use should be inflated about 4\%-10\% to derive a total estimate of waterfowl use for all 11 of SONEC's subregions.

The methods we used minimized, but likely did not eliminate, impacts of the inherent difficulties associated with estimating abundance of waterfowl from aerial surveys (Diem and Lu 1960, Smith et al. 1995, Prenzlow and Lovvorn 1996). As discussed above, we recognize that drab waterfowl that occurred singly or in small groups in vegetated habitats were probably missed at a higher rate than more brightly colored species that occurred in large groups in open habitats. Also, because private wetlands tend to be smaller and more ephemeral, we probably were more likely to miss waterfowl on private lands than on public wetland complexes; thus, our estimate that $75 \%$ of waterfowl use was on protected lands is likely inflated. Though we could not eliminate detection bias, it was minimized because our surveyors were well experienced and familiar with waterfowl ecology and habitats in the region. We used 2 survey aircraft to reduce survey duration and minimize the likelihood of waterfowl movement among survey areas, which could lead to double counting. Furthermore, we maintained consistency and continuity of the data by employing the same experienced surveyors and using the same survey procedures (e.g., the same high-winged aircraft and the same altitude, speed, and route) as during earlier surveys. Skills acquired over the many years during which these biologists conducted surveys in the region increased data quality, reduced variability, and helped minimize observer bias, which is 1 of the largest sources of survey error (Diem and Lu 1960, Smith 1995). Still, our survey design prevented us from estimating the precision of our abundance estimates; thus, any differences in the visibility rates or in the precision of abundance estimates among species, subregions, or time periods 
could lead to misinterpretation of results. Fortunately, comparison with telemetry data indicates that our aerial surveys accurately measured waterfowl use of SONEC during spring. Fleskes and Battaglia (2004) reported that an average of $68.3 \%$ (2002: $70.1 \%$; 2003: $66.4 \%$ ) of pintails that were radio-marked in the Central Valley of California during late winter used SONEC during the same springs as our study was conducted. This compares well with our SONEC surveys, which showed that the peak population of pintails in SONEC averaged $64.1 \%$ (2002: $74.3 \%$; 2003: $53.9 \%$ ) of the wintering population in California and southern Oregon. Thus, while we recognize that our surveys were pseudo-censuses without precision estimates, we believe that the comparison with radio-marked pintails supports our contention that our surveys provide not only the only available, but also a fairly accurate measure of spring waterfowl use in the region.

\section{Management Implications}

Our data quantifies the critical importance of the SONEC region to Pacific Flyway waterfowl during spring. Furthermore, our results indicate a possible need for a program to maintain and enhance spring habitats, especially on private lands, and to ensure that resources are adequate in years of below-average precipitation or when wintering waterfowl populations are larger than they were during 2002-2003. Water availability issues, like those well known for impacting fall waterfowl habitats in the Klamath Basin (Herald and News, Klamath Falls, Oregon, 8 April 2001 [available from: http://www.heraldandnews.com]), will undoubtedly also impact the ability of private and public area managers throughout SONEC to provide spring habitats. It is of great concern that a substantial proportion (25\%) of the spring waterfowl use that we observed occurred on unprotected habitat in SONEC. Furthermore, our diurnal surveys may underestimate the importance of private habitats to some species, including Northern Pintail, a species of concern because of continued low populations and the most common species in SONEC during spring. For instance, up to $84 \%$ of the night locations of radio-marked pintails in some subregions were on flooded pasture, which occurs primarily on private lands (Fleskes and Battaglia 2004). Thus, conservation of both public and private waterfowl habitats in SONEC is crucial for pintails and the numerous other waterfowl that migrate through the region on their way north to breeding areas from the Central Valley of California and other Pacific Flyway wintering areas.

\section{Future Research}

The SONEC region in the Great Basin has recently been identified as a new focus area for waterfowl habitat conservation efforts (M. Petrie, Ducks Unlimited, Inc., personal communication). In addition to estimates of waterfowl abundance and distribution that we provide here, data on habitat availability, habitat productivity, waterfowl food habits, and waterfowl energetic requirements during spring are needed to develop an energetics-based model to guide habitat conservation planning for the region. Additionally, we also need a better understanding of how annual variation in precipitation and changing water availability impact the carrying capacity of the SONEC landscape.

\section{ACKNOWLEDGMENTS}

We especially thank Jim Hainline, Elizabeth Huggins, Meg Laws, and Marty St. Louis for the many hours they spent conducting aerial waterfowl surveys throughout SONEC. We thank Mr. Tony Marnell, who through the Tuscany Research Institute of Las Vegas, Nevada, provided some operational funding for this project. The Tuscany Research Institute distributed a grant to Ducks Unlimited, Inc., in Memphis, Tennessee, which dispersed funds to the USGS Western Ecological Research Center and the California Waterfowl Association to conduct pintail research, of which this study was part. Funding was also provided by the USGS Science Support Program to address United States Fish and Wildlife Service research needs. USGS Western Ecological Research Center staff Bill Perry, Joan Daugherty, Stacy Burnett, and Laurie Williams provided GIS support; Daniel S. Battaglia and Luke Naylor helped summarize aerial survey results. We thank the rest of the PINSAT research team, including Mike Casazza, Michael Miller, John Takekawa, Dennis Orthmeyer, Mark Petrie, Bruce Batt, David Anderson, Fritz Reid, and Greg Yarris, for help in planning the project. We also thank Graham W. Smith, an anonymous reviewer, and the editors for their suggestions on improving the manuscript. 


\section{Literature Cited}

Anderson, W. 1957. A waterfowl nesting study in the Sacramento Valley, California, 1955. California Fish and Game 43:71-90.

1960. A study of waterfowl nesting in the Suisun Marshes. California Fish and Game 46:217-226.

Bellrose, F.C. 1980. Ducks, geese and swans of North America. 3rd edition. Stackpole Books, Harrisburg, PA. 540 pp.

DiEM, K.L., AND K.H. LU. 1960. Factors influencing waterfowl censuses in the parklands, Alberta, Canada. Journal of Wildlife Management 24:113-133.

Fleskes, J.P., and D.S. Battaglia. 2002. Pintail habitat use and abundance during spring migration in the Klamath Basin and other southern Oregon-northeastern California locations. Progress report 2002, United States Geological Survey, Western Ecological Research Center, Dixon, CA.

2004. Northern pintail habitat use and waterfowl abundance during spring migration in southern Oregon-northeast California (SONEC). Final report, United States Geological Survey, Western Ecological Research Center, Sacramento, CA.

Gilmer, D.S., J.L. LeE, D.M. Mauser, and J.L. Hainline. 2004. Waterfowl migration on Klamath Basin National Wildlife Refuges 1953-2001. Biological science report USGS/BRD/BSR-2003-2004, United States Geological Survey, Biological Resources Discipline.

Hothem, R.L., AND D. Welsh. 1994. Duck and shorebird reproduction in the grasslands of central California. California Fish and Game 80:68-79.

HunT, C.B. 1967. Physiography of the United States. W.H. Freeman, San Francisco, CA. 480 pp.

Klamath Basin Crisis. 2006. KBC News [cited 8 March 2006]. Available from: http://www.klamathbasincrisis .org

Klamath Tribal Council. 2001. Press release: December 2001: OSU water report [cited 8 March 2006]. Available from: http://www.klamathtribes.org/press waterup_dec2001.htm

Lindstrom, A. 2003. Fuel deposition rates in migrating birds: causes, constraints and consequences. Pages 307-320 in P. Berthold, E. Gwinner, and E. Sonnenschein, editors, Avian migration. Springer-Verlag, Berlin.

Miller, M.R., and D.C. Duncan. 1999. The Northern Pintail in North America: status and conservation needs of a struggling population. Wildlife Society Bulletin 27:788-800.

Miller, M.R., J.Y. TakeKaWa, J.P. Fleskes, D.L. ORTHmeyer, M.L. CASAZZA, AND W.M. Perry. 2005. Spring migration of Northern Pintails from California's Central Valley wintering area tracked with satellite telemetry: routes, timing, and destinations. Canadian Journal of Zoology 83:1314-1332.

NAYLOR, A.E. 1953. Production of the Canada Goose on Honey Lake Refuge, Lassen County, California. California Fish and Game 39:83-94.
Oregon Habitat Joint Venture. 2005. Newsletter of the Oregon Habitat Joint Venture: August 2005 [cited 7 March 2006]. West Linn, OR. Available from: http:// www.ohjv.org/pdfs/news0805.pdf

Prenzlow, D.M., AND J.R. LOVvorn. 1996. Evaluation of visibility correction factors for waterfowl surveys in Wyoming. Journal of Wildlife Management 60:286297.

Smith, D.R., K.J. Reinecke, M.J. Conroy, M.W. Brown, AND J.R. NASSAR. 1995. Factors affecting visibility rate of waterfowl surveys in the Mississippi Alluvial Valley. Journal of Wildlife Management 59:515-527.

Sмith, G.W. 1995. A critical review of the aerial and ground surveys of breeding waterfowl in North America: U.S. Department of the Interior, National Biological Service Biological Science Report 5. 252 pp.

Trost, R.E., and M.S. Drut. 2004. 2004 Pacific Flyway data book: waterfowl harvests and status, hunter participation and success, and certain hunting regulations in the Pacific Flyway and United States. United States Fish and Wildlife Service, Portland, OR.

United States Fish and Wildlife Service. 2000. Pacific Flyway, 1999-2000 fall and winter waterfowl survey report. United States Fish and Wildlife Service, Portland, OR.

2002. Winter waterfowl survey, Pacific Flyway2002. United States Fish and Wildlife Service, Portland, OR.

2003. Winter waterfowl survey, Pacific Flyway2003. United States Fish and Wildlife Service, Portland, OR.

[INTERNET]. Draft integrated pest management plan for Lower Klamath and Tule Lake NWRs [cited 7 March 2006]. Available from:http://library.fws.gov/ Pubs1/1PM/Current.html

United States Society for Irrigation and Drainage Professionals. 2006. Ground water and surface water under stress: competition, interaction, solutions [cited 18 April 2006]. Available from: http://www.uscid .org/06conf.html

University of CaLifornia, Santa CruZ. 1996. SUMP rotation research news [cited 7 March 2006]. Available from: http://gis.ucsc.edu/bode/newslet1.html

Western Regional Climate Center. [internet](A). California climate narrative [cited 14 January 2004]. Available from: http://www.wrcc.dri.edu/narratives/ California.htm

[INTERNET] (B). Oregon climate narrative [cited 14 January 2004]. Available from:http://www.wrcc.dri edu/narratives/ Oregon.htm

. [INTERNET](C). Western United States climate historical summaries [cited 14 January 2004]. Available from: http://www.wrcc .dri.edu/climsum.html . [INTERNET](D). Standardized precipitation index [cited 2 March 2004]. Available from: http://www .wrcc.dri.edu/spi/spi.html

Received 20 April 2006

Accepted 8 January 2007 